\title{
Effect of physicochemical parameters on Anopheles and Culex mosquito larvae abundance in different breeding sites in a rural setting of Muheza, Tanzania
}

\author{
Basiliana Emidi ${ }^{1,2^{*}}$, William N. Kisinza ${ }^{3}$, Bruno P. Mmbando ${ }^{4}$, Robert Malima ${ }^{3}$ and Franklin W. Mosha ${ }^{1}$
}

\begin{abstract}
Background: Malaria and lymphatic filariasis (LF) are diseases of great public health important in East Africa. Malaria is transmitted by Anopheles while LF is transmitted by both Anopheles and Culex mosquitoes. There is limited evidence on the effects of physicochemical parameters on these mosquitoes in rural settings of Tanzania. This study aimed at assessing the effects of physicochemical parameters on Anopheles and Culex larvae abundance in different breeding sites in a rural setting of Muheza district.

Methods: A cross-sectional study was conducted in 13 villages in Muheza district, between December 2015 and May 2016. Mosquito larvae were sampled using standard dipping techniques. Physicochemical parameters were measured by a Multi-parameter pH meter in different mosquito breeding sites. Mosquito larvae and pupa densities were compared between the $\leq 33$ th (lower) and $\geq 67$ th (upper) percentiles of physicochemical parameters. An. gambiae (s.l.) and An. funestus were identified by polymerase chain reaction (PCR) to reveal their sibling species.

Results: Abundance of Anopheles larvae was significantly higher (76.6\%) than Culex (66.9\%) $\left.X^{2}=5.73, d f=1, P=0.017\right)$. The presence of late instars of Anopheles was significantly higher (78.2\%) than that of Culex (64.5\%) $\left(x^{2}=0.984, d f=1\right.$, $P=0.017$ ). A model adjusted for larval stage showed that the likelihood of finding Culex larvae was lower by $38.2 \%$ (95\% Cl: 16.9-54.1, $d f=1, P=0.001$ ) compared to Anopheles. Upper percentiles of salinity (OR $=7.05 ; 95 \%$ Cl: 1.19-41.88, $P=0.032)$ and conductivity $(\mathrm{OR}=5.47 ; 95 \% \mathrm{Cl}: 1.01-29.67, P=0.056)$ were significantly associated with the presence and with increased density of Anopheles larvae. PCR results showed that, within the gambiae complex, 53.3\% ( $n=136)$ were An. gambiae (s.s.) and 46.7\% ( $n=119)$ were An. arabiensis. In An. funestus group, 91.1\% $(n=41)$ were An. funestus (s.s.), 4.4\% ( $n=2)$ were An. rivulorum, 2.2\% ( $n=1)$ were An. leesoni and 2.2\% $(n=1)$ were An. parensis.

Conclusion: High salinity and conductivity were significantly associated with increased density of Anopheles larvae. To our knowledge, this is the first study to demonstrate the occurrence of Anopheles larvae in polluted breeding sites in rural settings of Tanzania. The study has found both Anopheles and Culex mosquito larvae co-existed in breeding sites. The possible reasons for tolerance to a higher level of physicochemical parameters among Anopheles mosquitoes need to be ascertained.
\end{abstract}

Keywords: Anopheles, Culex, Mosquitoes, Breeding sites, Physicochemical parameters, Muheza, Tanzania

\footnotetext{
* Correspondence: ebasi2002@gmail.com

${ }^{1}$ Kilimanjaro Christian Medical University College, P.O. Box 2240, Moshi,

Tanzania

${ }^{2}$ National Institute for Medical Research, Headquarters, P.O. Box 9653, Dar es

Salaam, Tanzania

Full list of author information is available at the end of the article
} 


\section{Background}

Malaria and lymphatic filariasis are diseases of significant public health importance in East Africa [1-3]. Malaria is transmitted by anopheline mosquitoes, while lymphatic filariasis is transmitted by both Anopheles and Culex mosquitoes $[2,4,5]$. These vectors breed in various habitats $[6,7]$. For instance, whereas $A n$. gambiae (s.l.) breed in small, open, sunlit, fresh water bodies, $A n$. funestus normally breed in water bodies with emergent vegetation such as swamps and rice fields. Culex quinquefasciatus breed in polluted water habitats such as pit latrines, soak pits, cesspits and open sewage systems $[6,8]$.

The breeding sites of these mosquitoes are sometimes contaminated with pollutants from various sources such as sewage and fertilisers from agricultural fields $[9,10]$. Physicochemical characteristics of mosquito breeding sites may have some effect on mosquito vectors oviposition, survival and spatial distribution [9]. Physicochemical parameters such as temperature, salinity, conductivity, total dissolved solids (tds) and $\mathrm{pH}$ have a significant influence on the occurrence and larval abundance among mosquito species $[8,11,12]$. High levels of conductivity may be due to the application of agricultural pesticides and herbicides [9].

Climatic factors such as moisture index and temperature also have strong effects on the distribution and abundance of malaria vectors [13-16]. Mosquito vector distribution is to a large extent influenced by climatic conditions and species habits across the globe $[6,17,18]$. Their population densities vary with seasons due to fluctuating availability of favourable breeding sites [19]. Availability, distribution and abundance of mosquitoes depend on types of breeding sites including water surface area and other biological factors $[20,21]$. The density of adult mosquitoes is determined by the number and productivity of larval habitats and their proximity to human hosts where they can obtain a blood meal [22]. A better understanding of breeding behavioural patterns among mosquito populations is one of the key elements for reaching the goal of malaria and lymphatic filariasis elimination and eradication [7, 23]. While various factors affecting the breeding of Culex and Anopheles mosquitoes have been documented, there is limited evidence on the effects of physicochemical parameters on these mosquito vectors in sub-Saharan Africa. This study, therefore, aimed at assessing the effects of physicochemical parameters on Anopheles and Culex larvae abundance in different breeding sites in a rural setting of Muheza district, Tanzania.

\section{Methods}

\section{Study area}

This study was conducted in Muheza district along the north-eastern coast of Tanzania. Muheza is $4922 \mathrm{~km}^{2}$, and it is located $5^{\circ} 10^{\prime} \mathrm{S}, 38^{\circ} 46^{\prime} \mathrm{E}$. The district stretches from a coastal plain at sea level to the Usambara
Mountains at an elevation of $1050 \mathrm{~m}$ above sea level (Fig. 1). According to the 2012 Population and Housing Census, the district had a total of 204,461 people, of whom 100,843 (49.3\%) were males while 103,618 (50.7\%) were females [24]. The climate is tropical, with dense rainforest cover over the Usambara mountain ranges with annual rainfall $1000-2000 \mathrm{~mm}$. Muheza district is mainly inhabited by subsistence farmers, where rain-fed rice, maize, oranges and vegetables are the main crops. Administratively, Muheza district is divided into 6 divisions comprised of 35 wards with 175 villages [24].

The dominant mosquito species include $A n$. gambiae (s.l.), An. funestus and Culex quinquefasciatus. These vectors are most abundant during the rainy seasons, which include long rains in April to September and short rains in December to January.

\section{Study design and sites}

This was a cross-sectional study that involved 13 villages, which were each visited once between December 2015 and May 2016. The selected villages included Kicheba, Mamboleo, Mkuzi-2, Bwembwera, Kibaoni-2, MamboleoLusanga, Mbaramo, Mianga, Mkurumilo, Pangamlima, Songakibaoni-2, Umba and Zeneti. The villages were surveyed for mosquito breeding sites and their physicochemical parameters. During the survey, a total of 31 sampling points with eight types of breeding sites (rainwater collections, rice fields, animal hoof-prints, swamps, roadside water collections and road potholes, pond water reservoirs, small ponds and water collections on the sides of the bridge) were surveyed (Fig. 2). During analysis, each village's measurements of physicochemical parameters were to some extent expected to reflect the season of sampling and were independent of seasons.

\section{Mosquito larvae sampling and rearing}

To obtain adult mosquitoes for morphological identification, larvae were sampled using a standard dipping technique from various breeding sites in each village using two types of dipper. One was the standard dipper described by WHO [7] and the other was an improvised dipper described by Emidi et al. [25] which is suitable for small breeding sites such as animal hoof prints. A total of 50 to 100 mosquito larvae were collected per village and reared at the insectary for morphological identification of emerging adults. The number of mosquito larvae ranged from 50 to 100 among the villages sampled. Only 50 larvae were collected from Mkurumilo and Umba villages while 100 larvae were obtained from rest of the villages. These larvae were pooled per village irrespective of their breeding sites. Emerging adult mosquitoes were morphologically identified using a morphological key by Gillies \& DeMeillon [26] for Anopheles species and Edwards [27] for culicines. However, adult 


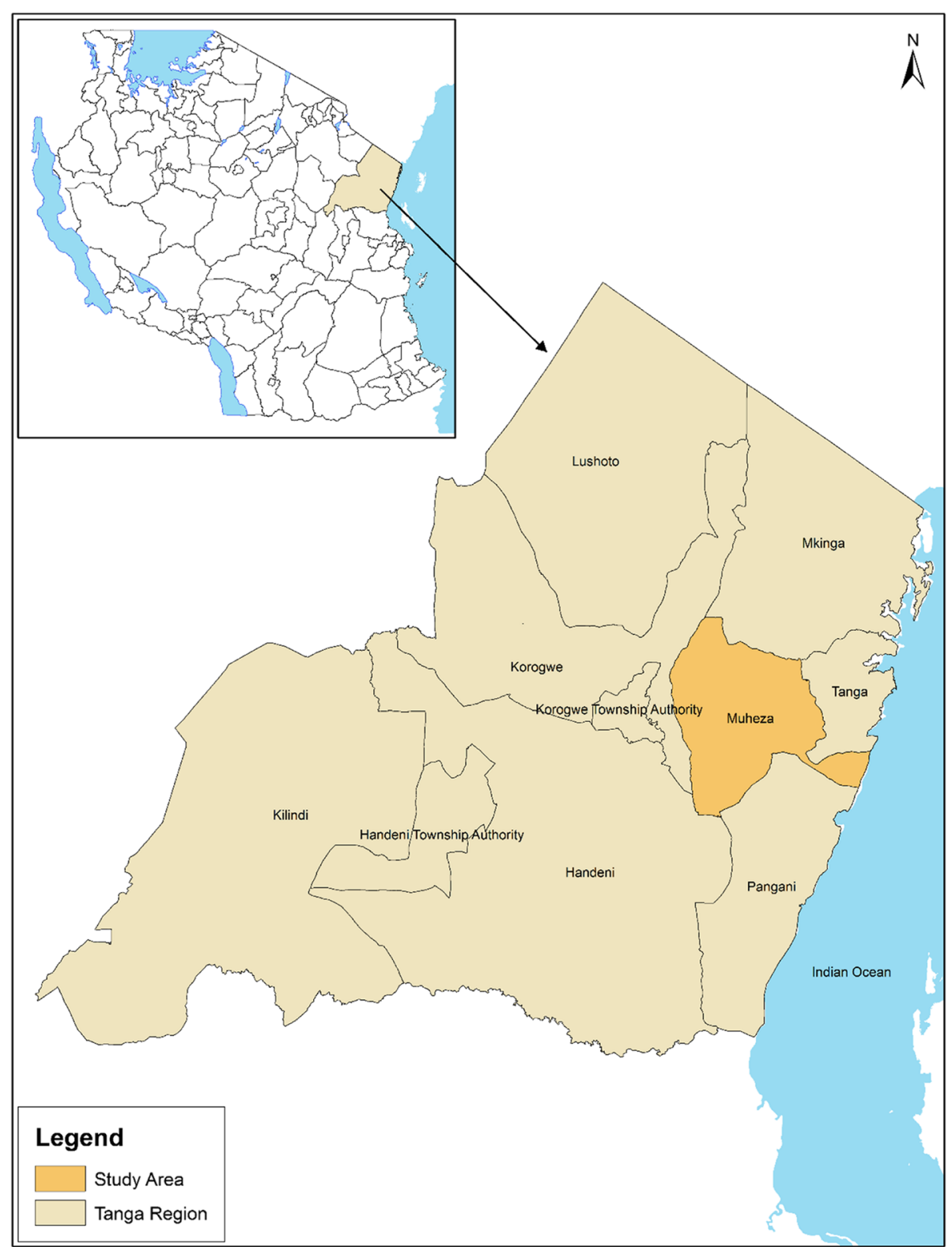

Fig. 1 Map of Tanga region showing Muheza District

An. gambiae (s.l.) and An. funestus were preserved in silica gel for further molecular identification of their sibling species by quantitative real-time polymerase chain reaction (qPCR).

\section{Molecular identification of sibling species of An. gambiae (s.l.) and An. funestus group}

Out of 1250 emerged adult mosquitoes of An. gambiae (s.l.) and An. funestus group, a total of 320 mosquitoes were identified by qPCR as described in [28] to reveal the identity of the sibling species.

\section{Collection of physicochemical parameters data}

Physicochemical parameters (temperature, $\mathrm{pH}$, conductivity, tds and salinity) were measured using a multiparameter $\mathrm{pH}$ meter (Eutech PCSTEST35-01X441506/ Oakton 35,425-10, Vernon Hills, Illinois, 60,061, USA) based on guidelines provided by the manufacturer. The multiparameter $\mathrm{pH}$ meter was calibrated before use. A total of four replicate measurements were recorded per breeding site. All mosquito breeding sites encountered were sampled. A total of 31 sampling points was surveyed, and variations in the frequency of sampling per village depended on the availability of breeding sites. 

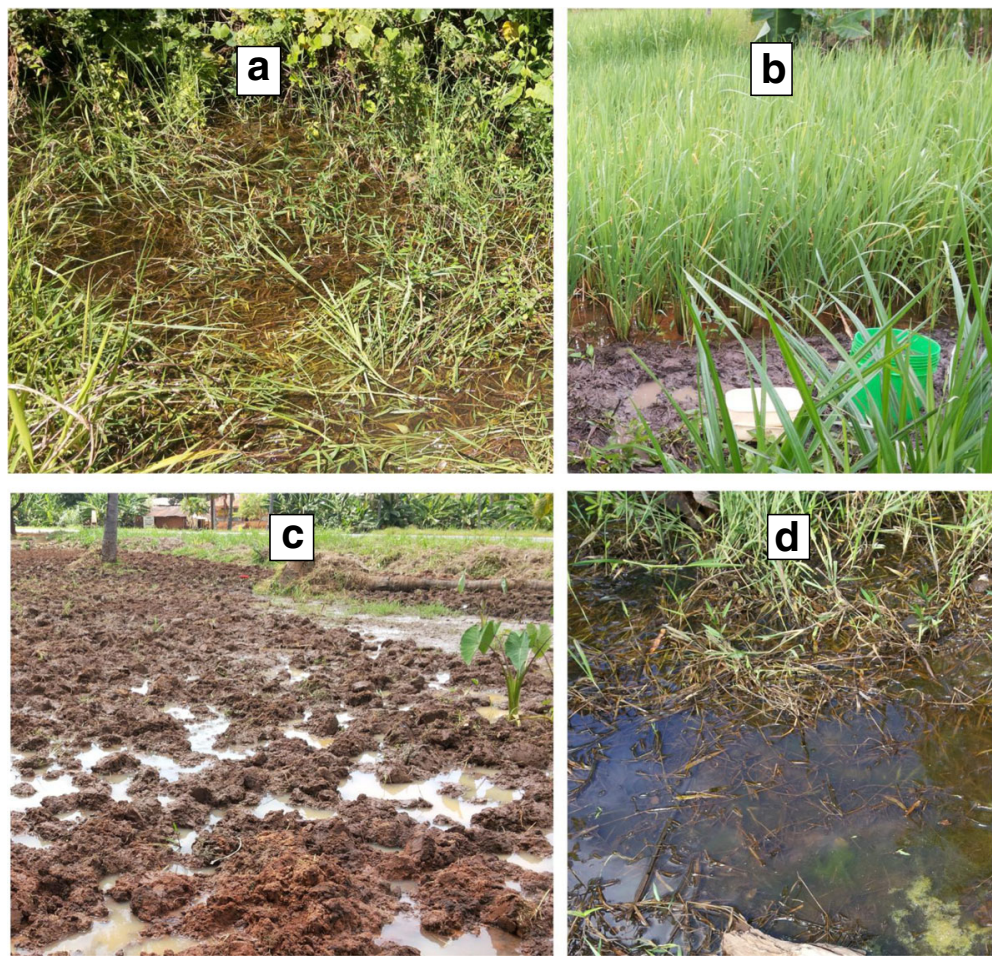

Fig. 2 Mosquito breeding sites. a Swamp. b Rice-fields. c Hoof-prints. d Rainwater collections

\section{Data analysis}

Data were analysed in Microsoft Excel and the Stata 13 and R 3.3.0 statistical packages. Categorical data were summarised by cross tabulation and compared using chi-square. Continuous variables were summarised using mean and standard deviation and compared using Student's t-test for independent samples. Mosquito larvae densities were highly skewed and so were square root-transformed. Presence/absence and density of the larvae and pupae in the breeding sites were modelled using generalised estimating equation (GEE) for binary and continuous data, respectively. The GEE model was chosen because data were correlated between breeding sites and in replications. The binary GEE model was used to determine the importance of different levels of the physicochemical parameters on the presence of mosquito larvae or pupae, while the linear GEE was used to determine the association between the transformed larvae and pupae densities and physiochemical parameters. Both, univariate and multivariate models were fitted, and estimates were reported with robust $95 \%$ confidence intervals (95\% CI). Physicochemical parameters were categorised into three groups; $\leq 33 \mathrm{rd}$, 33-66th and $\geq 67$ th percentiles to increase the power by increasing the variability of larvae and pupae densities by the group of physicochemical parameters. This categorization was selected after the model fitting physiochemical parameters as a continuous variable, revealed low power in order to attain the significant levels of the coefficients. The comparisons were made between the first and the last groups, which in this paper will be referred to as lower and upper percentiles, respectively.

Mosquito breeding sites with comparatively smaller variations in mean values of the physicochemical parameters were grouped together to reduce the number of breeding sites. A total of six breeding site types were obtained following pooling of mosquito breeding sites: (i) rain water collections; (ii) road-side water collections and road potholes; (iii) rice fields and animal hoof prints; (iv) swampy areas; (v) pond water reservoirs; and (vi) small ponds and water collections on the sides of bridges. In all analyses, a $P$-value of $<0.05$ was considered statistically significant. During analysis, each village measurements of physicochemical parameters were independent of seasons and mosquito breeding site type.

\section{Results}

Dominant breeding site types and their frequency in surveyed villages

All breeding sites encountered during the survey were sampled. Among the mosquito breeding sites sampled, the ones with high frequencies of occurrence were described as "dominant breeding sites". Out of 31 encountered sampling points, 10 (32.3\%) were swamped, and 7 (22.7\%) were rainwater collection ponds; these constituted the dominant breeding sites. Regarding the number of 
habitats from each village; Mkuzi, Mamboleo and Kicheba villages had four breeding sites each; Mbaramo had one while the rest had had two breeding sites each. The types and frequencies of breeding sites per village are shown in Table 1. During analysis, the breeding sites with minimal difference in physicochemical parameters were combined as described in the data analysis section.

Temporary breeding sites can contain water for several weeks but normally dry up after the rainy season while permanent breeding sites can contain water even after the rainy season. In the context of this study, temporary breeding sites were rainwater collections, roadside water collections and tyre prints, rice fields and animal hoof prints and ponds/small ponds and road potholes while permanent breeding sites were swampy areas and pond water reservoirs. The main sources of water for these breeding sites are rainfall.

\section{Mosquito mean larvae and pupae abundance}

Anopheles and Culex mosquito species were found to co-exist in the breeding sites. The overall mean abundance of larval stages 1 and 2 (early instars) of Anopheles was 11.2 larvae per dipper while that of Culex was 11.6 and the difference was not significant $\left(t_{(60)}=-0.08\right.$, $P=0.9$ ). The mean abundance for larval stages 3 and 4 (late instars) of Anopheles was 8.2 larvae per dipper while that of Culex was 10.3, and these were not significantly different $\left(t_{(60)}=-0.75, P=0.45\right)$. There was no significant difference in the mean density of pupae across the breeding site types (Kruskal-Wallis test, $\chi^{2}=3.53, d f=5, P=0.619$ ).
There were more immature stages of Anopheles than Culex in the sites surveyed; the probability of finding Anopheles larvae was $76.6 \%$, while that of finding Culex was $66.9 \%,\left(\chi^{2}=5.73, d f=1, P=0.017\right)$. The occurrence of early instars was similar between the Anopheles (75\%) and Culex (69.3\%), $\left(\chi^{2}=0.984, d f=1, P=0.321\right)$, while that of late instars, was significantly higher in Anopheles (78.2\%) than in Culex (64.5\%), $\left(\chi^{2}=5.70, d f=1\right.$, $P=0.017)$. The GEE model adjusted for larval stage showed that the likelihood of finding Culex larvae was lower by $38.2 \%$ (95\% CI: $16.9-54.1, d f=1, P=0.001$ ) compared to Anopheles.

\section{Identification of adult mosquito, and An. gambiae (s.l.) and $A n$. funestus sibling species}

Two mosquito genera obtained from reared larvae were Anopheles and Culex. Upon morphological identification of adult mosquitoes, several species of mosquitoes were obtained. The genus Anopheles was comprised of $A n$. gambiae (s.l.), An. funestus group, An. coustani and An. maculipalpis while the genus Culex comprised of $C x$. quinquefasciatus and $C x$. cinereus species. The male/female ratio of emerged mosquitoes was almost equal to 1:1. Anopheles funestus mosquitoes were collected from Zeneti village only. Our target mosquito species were An. gambiae (s.l.), An. funestus group and Cx. quinquefasciatus. Other species of mosquitoes obtained such as An. coustani, An. maculipalpis and $C x$. cinereus were discarded after sorting.

Regarding the An. gambiae (s.l.) and An. funestus sibling species, a total of 320 Anopheles mosquitoes were further identified to sibling species by qPCR. Results

Table 1 Types and frequency of breeding sites per village

\begin{tabular}{|c|c|c|c|c|c|c|c|c|c|c|}
\hline & \multirow[b]{2}{*}{ Villages } & \multicolumn{8}{|c|}{ Breeding site type code } & \multirow{2}{*}{$\begin{array}{l}\text { Frequency of breeding } \\
\text { sites per village }\end{array}$} \\
\hline & & 1 & 3 & 4 & 5 & 6 & 7 & 11 & 13 & \\
\hline 1 & Mkuzi & 4 & 0 & 0 & 0 & 0 & 0 & 0 & 0 & 4 \\
\hline 2 & Kicheba & 0 & 0 & 0 & 0 & 0 & 3 & 1 & 0 & 4 \\
\hline 3 & Umba & 0 & 0 & 0 & 2 & 0 & 0 & 0 & 0 & 2 \\
\hline 4 & Kibaoni-2 & 1 & 0 & 0 & 0 & 1 & 0 & 0 & 0 & 2 \\
\hline 5 & Zeneti & 0 & 1 & 1 & 0 & 0 & 0 & 0 & 0 & 2 \\
\hline 6 & Mamboleo-Lusanga & 0 & 0 & 0 & 2 & 0 & 0 & 0 & 0 & 2 \\
\hline 7 & Bwembwera & 0 & 0 & 1 & 0 & 1 & 0 & 0 & 0 & 2 \\
\hline 8 & Mbaramo & 0 & 0 & 0 & 1 & 0 & 0 & 0 & 0 & 1 \\
\hline 9 & Songakibaoni-2 & 1 & 0 & 0 & 1 & 0 & 0 & 0 & 0 & 2 \\
\hline 10 & Mkurumilo & 0 & 0 & 0 & 0 & 1 & 0 & 0 & 1 & 2 \\
\hline 11 & Mianga & 0 & 0 & 0 & 1 & 0 & 0 & 0 & 1 & 2 \\
\hline 12 & Pangamlima & 1 & 0 & 0 & 0 & 1 & 0 & 0 & 0 & 2 \\
\hline \multirow[t]{2}{*}{13} & Mamboleo & 0 & 1 & 0 & 3 & 0 & 0 & 0 & 0 & 4 \\
\hline & Total types of breeding sites & 7 & 2 & 2 & 10 & 4 & 3 & 1 & 2 & 31 \\
\hline
\end{tabular}

Key: 1, rain water collections; 3 , rice fields; 4 , animal hoof prints; 5 , swampy areas; 6 , road side water collections and road potholes; 7 , pond water reservoirs; 11 , small ponds; 13 , water collections on sides of the bridges 
from PCR have shown that, within the An. gambiae complex, only two sibling species were identified. Out of 255 An. gambiae complex, 53.3\% $(n=136)$ were $A n$. gambiae (s.s.) and $46.7 \%(n=119)$ were An. arabiensis. There were no $A n$. merus identified. In addition, four sibling species within the An. funestus group were identified. Out of 45 An. funestus group, 91.1\% $(n=41)$ were An. funestus (s.s.), 4.4\% $(n=2)$ were An. rivulorum, 2.2\% $(n=1)$ were An. leesoni and 2.2\% $(n=1)$ were $A n$. parensis. None amplified samples accounted for $6.7 \%(n=20)$.

\section{Physicochemical parameters of different breeding sites}

Table 2, shows the categorization of physicochemical parameters measured in the mosquito breeding sites. Lower percentile of salinity ranged from $107.0-245.0 \mathrm{ppm}$ while higher percentiles ranged from 576.9-1190.0 ppm. Other percentiles and variables are as shown in Table 2. The higher percentiles in our model were more stringent than those reported from other categorizations [29].

\section{Effect of physicochemical parameters on the presence or absence of mosquito larvae}

Results from GEE model for the parameters associated with presence or absence of mosquito larvae showed that upper percentiles of salinity $(\mathrm{OR}=7.05$; 95\% CI: $1.19-41.88, P=0.032$ ) and conductivity $(\mathrm{OR}=5.47 ; 95 \%$ CI: $1.01-29.67, P=0.056)$ were strongly associated with the presence of Anopheles larvae. Although not statistically significant, high tds was associated with the presence of Anopheles larvae and pupae. None of the parameters was found to be significantly associated with the presence of Culex larvae. Additionally, breeding site types had no significant effect on the presence of mosquito larvae and pupae (Table 3).

\section{Association between physiochemical parameters on} Anopheles and Culex mosquito larvae, and pupa densities Table 4 shows the means \pm standard deviations of physicochemical parameters in the six categories of various mosquito breeding sites. Total dissolved solids (tds) were highest in pond water reservoirs $(990 \pm 550.7 \mathrm{ppm})$ and lowest in the small ponds and water collection on bridge sides $(249.3 \pm 103.9)$. The $\mathrm{pH}$ in all breeding sites was weak basic. Salinity and conductivity were recorded highest in the pond water reservoirs with $809.2 \pm 453.9 \mathrm{ppm}$ and $1336 \pm 738.1 \mu \mathrm{S}$, respectively.

In general, the association between mean larval and pupa densities of Anopheles and Culex were highest in breeding sites (category ii) comprising roadsides water collections and in road potholes (Table 4). This category had the highest $\mathrm{pH}$ and the second lowest salinity and conductivity values. The lowest larvae and pupae densities were found in pond water reservoirs (category v). This category had highest mean temperature, tds, salinity and conductivity. Surprisingly, except for temperature, which was the lowest, this site had the highest standard deviations of all physicochemical parameters. The mean values of these parameters remained consistently high even when data were $\log$-transformed.

Table 5 shows results from GEE model based on lower and uppers percentiles of physicochemical parameters in different breeding sites on mosquito larvae and pupae (square root-transformed) densities. The type of breeding site was associated with the larvae and pupa densities wherein the univariate model, breeding site types such as rice fields and animal hoof prints as well as small pond water reservoirs had significantly lower densities of Culex larvae. However, in the multivariate analysis, Anopheles larval density was significantly lower in only small pond water reservoirs. None of the breeding sites was statistically significant for Culex larvae.

In the univariate analysis, upper percentiles of salinity and conductivity were significantly associated with

Table 2 Distribution of levels of physicochemical parameter percentiles when compared to standard categories

\begin{tabular}{lllll}
\hline Parameter & Percentile & $\begin{array}{l}\text { Range } \\
(\text { min-max })\end{array}$ & Standard range [29] & Description [29] \\
\hline Salinity $(\mathrm{ppm})$ & $\leq 33 \%$ & $107.0-245.0$ & $<500$ & Fresh water \\
& $\geq 67 \%$ & $576.9-1190.0$ & $\geq 500$ & Polluted water \\
Temperature $\left({ }^{\circ} \mathrm{C}\right)$ & $\leq 33 \%$ & $24.5-30.4$ & $<35$ & Normal temperature \\
& $\geq 67 \%$ & $36.6-42.8$ & & Hot \\
Total dissolved solids $(\mathrm{ppm})$ & $\leq 33 \%$ & $131.0-289.0$ & $<400$ & Mineral springs \\
& $\geq 67 \%$ & $701.0-1450.0$ & $\geq 400$ & High contamination \\
Conductivity $(\mu \mathrm{S})$ & $\leq 33 \%$ & $200.0-411.0$ & $<800$ & Domestic water \\
& $\geq 67 \%$ & $1007.0-1970.0$ & $\geq 800$ & Highly polluted \\
$\mathrm{pH}$ & $\leq 33 \%$ & $7.0-7.9$ & 7 & Neutral \\
& $\geq 67 \%$ & $8.4-11.0$ & Weak basic \\
\hline
\end{tabular}


Table 3 Association between presence of mosquito larvae and pupae densities with breeding site type and physicochemical parameters

\begin{tabular}{|c|c|c|c|}
\hline \multirow[t]{2}{*}{ Parameter } & Anopheles larvae & Culex larvae & Pupae (Culex and Anopheles) \\
\hline & OR $(95 \%$ Cl); $P$-value & OR $(95 \% \mathrm{Cl}) ; P$-value & OR (95\% Cl); P-value \\
\hline \multicolumn{4}{|l|}{ Breeding site type } \\
\hline (i) Rain water collections & 1 & 1 & 1 \\
\hline (ii) Road side water collections and road potholes & $0.83(0.11-6.38) ; 0.858$ & $2.12(0.17-26.11) ; 0.559$ & $0.67(0.06-7.54) ; 0.743$ \\
\hline (iii) Rice fields and animal hoof prints & $0.68(0.05-10.0) ; 0.781$ & $0.18(0.02-1.68) ; 0.133$ & $1.2(0.07-20.56) ; 0.900$ \\
\hline (iv) Swampy areas & 0.99 (0.17-5.58); 0.988 & $0.97(0.15-6.24) ; 0.975$ & $1.2(0.15-9.29) ; 0.861$ \\
\hline (v) Pond water reservoirs & $0.46(0.04-5.02) ; 0.528$ & $0.22(0.03-1.84) ; 0.161$ & $0.29(0.03-2.65) ; 0.270$ \\
\hline $\begin{array}{l}\text { (vi) Small ponds and water collections } \\
\text { on the sides of the bridges }\end{array}$ & $0.10(0.01-1.70) ; 0.110$ & $0.30(0.03-3.47) ; 0.337$ & $0.2(0.01-3.84) ; 0.286$ \\
\hline \multicolumn{4}{|l|}{ Physicochemical parameter } \\
\hline Salinity (ppm) & $7.05(1.19-41.88) ; 0.032^{\mathrm{a}}$ & $1.22(0.3-4.93) ; 0.78$ & $3.51(0.73-16.83) ; 0.117$ \\
\hline Temperature $\left({ }^{\circ} \mathrm{C}\right)$ & $2.65(0.59-11.73) ; 0.197$ & $0.4(0.11-1.48) ; 0.17$ & $0.55(0.12-2.67) ; 0.456$ \\
\hline Total dissolved solids (ppm) & $4.20(0.71-24.87) ; 0.113$ & $0.79(0.2-3.08) ; 0.73$ & $3.23(0.66-15.86) ; 0.149$ \\
\hline Conductivity ( $\mu S$ ) & $5.47(1.01-29.67) ; 0.057^{\mathrm{a}}$ & $0.76(0.2-2.83) ; 0.68$ & $2.84(0.62-13.06) ; 0.180$ \\
\hline $\mathrm{pH}$ & $0.45(0.11-1.85) ; 0.218$ & $0.66(0.19-2.2) ; 0.49$ & $0.48(0.174-1.31) ; 0.153$ \\
\hline
\end{tabular}

Abbreviation: $O R$ odds ratio

${ }^{a}$ Statistically significant

increased density of Anopheles larvae. The mean square root larval density was higher by 1.86 (95\% CI: $0.59-3.12$, $P=0.004$ ) in upper percentiles of salinity compared to lower percentiles. For Culex larvae, temperature and $\mathrm{pH}$ were both associated with decrease in square root larval density by 1.75 (95\% CI: $0.12-3.36, P=0.035)$ and 0.74 (95\% CI: 0.06-1.42, $P=0.034$ ), respectively (Table 5).

Table 6 shows the GEE model based on lower and upper percentiles of physicochemical parameters in different breeding sites on pupae density (square root-transformed). Pupae density was significantly higher in breeding sites such as rice fields and animal hoof prints, swampy areas and small pond water reservoirs compared to rain water collections. Regarding the physicochemical parameters, the only temperature had statistically significant effect; and it was associated with a decrease in the square root of pupae density by 1.66 (95\% CI: $0.75-2.57, P<0.0001)$.
In the multivariate model, tds and conductivity were excluded from the model due to their high colinearity with salinity (Fig. 3). The correlation coefficients between either of the two parameters were above $95 \%$, which means that variation observed due to salinity could be explained by either of the two parameters. This model showed that the effect of the physicochemical parameters remained the same in exception of $\mathrm{pH}$ which turned out to be significant in the model as well as salinity which showed the slightly improved effect on Anopheles larvae density.

\section{Discussion}

Our results indicate that presence of various physicochemical parameters in mosquito breeding sites at various levels has some influence on mosquito vector oviposition, survival and spatial distribution. Some physicochemical parameters appeared to significantly influence the larval

Table 4 Distribution of mean levels of physicochemical parameters and mosquito larvae and pupae densities by breeding site type

\begin{tabular}{|c|c|c|c|c|c|c|c|c|}
\hline $\begin{array}{l}\text { Breeding site type } \\
\text { categories }(n)\end{array}$ & $\begin{array}{l}\text { Temperature } \\
\text { (mean } \pm \mathrm{SD})\end{array}$ & $\begin{array}{l}\text { Tds } \\
\text { (mean } \pm S D)\end{array}$ & $\begin{array}{l}\mathrm{pH} \\
(\text { mean } \pm \mathrm{SD})\end{array}$ & $\begin{array}{l}\text { Salinity } \\
\text { (mean } \pm \mathrm{SD})\end{array}$ & $\begin{array}{l}\text { Conductivity } \\
\text { (mean } \pm \text { SD) }\end{array}$ & $\begin{array}{l}\text { Anopheles } \\
\text { (mean } \pm \text { SD) }\end{array}$ & $\begin{array}{l}\text { Culex } \\
\text { (mean } \pm \mathrm{SD})\end{array}$ & $\begin{array}{l}\text { Pupae } \\
\text { (mean } \pm \text { SD) }\end{array}$ \\
\hline (i) Rain water collections (7) & $33.0 \pm 4.7$ & $558.3 \pm 260.8$ & $8.0 \pm 0.5$ & $464.8 \pm 248.8$ & $653.9 \pm 311.5$ & $11.0 \pm 9.7$ & $15.6 \pm 13.0$ & $8.0 \pm 7.1$ \\
\hline $\begin{array}{l}\text { (ii) Road side water collections } \\
\text { and road potholes (4) }\end{array}$ & $32.2 \pm 5.8$ & $323.9 \pm 245.0$ & $8.8 \pm 1.6$ & $279.6 \pm 201.1$ & $454.9 \pm 370.8$ & $13.0 \pm 14.0$ & $21.6 \pm 19.6$ & $10.5 \pm 12.6$ \\
\hline $\begin{array}{l}\text { (iii) Rice fields and animal } \\
\text { hoof prints (4) }\end{array}$ & $35.2 \pm 3.2$ & $633.1 \pm 143.4$ & $8.5 \pm 1.1$ & $520.6 \pm 140.6$ & $945.3 \pm 265.2$ & $10.0 \pm 7.4$ & $1.6 \pm 1.9$ & $3.1 \pm 2.3$ \\
\hline (iv) Swampy areas (10) & $32.8 \pm 4.7$ & $529.1 \pm 278.4$ & $8.1 \pm 0.8$ & $428.9 \pm 242.1$ & $770.1 \pm 409.1$ & $10.0 \pm 6.9$ & $10.4 \pm 8.6$ & $4.1 \pm 4.8$ \\
\hline (v) Pond water reservoirs (3) & $41.9 \pm 0.8$ & $990.0 \pm 550.7$ & $8.3 \pm 0.0$ & $809.2 \pm 453.9$ & $1336.0 \pm 738.1$ & $3.5 \pm 2.8$ & $0.9 \pm 0.9$ & $0.8 \pm 0.7$ \\
\hline $\begin{array}{l}\text { (vi) Small ponds and water } \\
\text { collections on the sides of } \\
\text { the bridges (3) }\end{array}$ & $28.7 \pm 2.6$ & $249.3 \pm 103.9$ & $8.5 \pm 0.1$ & $176.0 \pm 58.8$ & $335.7 \pm 117.1$ & $7.1 \pm 12.3$ & $9.3 \pm 15.2$ & $5.2 \pm 8.9$ \\
\hline
\end{tabular}


Table 5 Univariate and multivariate association between larvae densities with physiochemical parameters and breeding site-type

\begin{tabular}{|c|c|c|c|c|}
\hline \multirow[t]{2}{*}{ Parameter } & \multicolumn{2}{|l|}{ Univariate } & \multicolumn{2}{|l|}{ Multivariate } \\
\hline & Coefficient (95\% Cl) & $P$-value & Coefficient $(95 \% \mathrm{Cl})$ & $P$-value \\
\hline \multicolumn{5}{|l|}{ Anopheles larvae } \\
\hline \multicolumn{5}{|l|}{ Breeding site type category } \\
\hline (i) Rain water collections & 1 & & 1 & \\
\hline (ii) Road side water collections and road potholes & $0.08(-2.22--2.37)$ & 0.947 & $-0.35(-1.84-1.15)$ & 0.650 \\
\hline (iii) Rice fields and animal hoof prints & $-0.17(-2.11-1.76)$ & 0.860 & $-2.1(-5.05-0.85)$ & 0.162 \\
\hline (iv) Swampy areas & $-0.19(-1.65-1.26)$ & 0.795 & $-0.36(-1.86-1.13)$ & 0.633 \\
\hline (v) Pond water reservoirs & $-1.36(-2.93-0.21)$ & 0.089 & $-2.02(-3.42--0.62)$ & $0.005^{\mathrm{a}}$ \\
\hline $\begin{array}{l}\text { (vi) Small ponds and water collections } \\
\text { on the sides of the bridges }\end{array}$ & $-1.31(-4.07-1.45)$ & 0.351 & $0.001(-3.00-3.00)$ & 0.999 \\
\hline Salinity (ppm) & $1.86(0.59-3.12)$ & $0.004^{a}$ & $2.55(1.44-3.66)$ & $<0.001^{a}$ \\
\hline Temperature $\left({ }^{\circ} \mathrm{C}\right)$ & $0.06(-1.40-1.52)$ & 0.94 & & \\
\hline Total dissolved solids (ppm) & $1.35(-0.01-2.70)$ & 0.051 & & \\
\hline Conductivity $(\mu \mathrm{S})$ & $1.62(0.24-3.00)$ & $0.022^{\mathrm{a}}$ & & \\
\hline $\mathrm{pH}$ & $-0.45(-1.26-0.35)$ & 0.271 & & \\
\hline \multicolumn{5}{|l|}{ Culex larvae } \\
\hline \multicolumn{5}{|l|}{ Breeding site type category } \\
\hline (i) Rain water collections & 1 & & 1 & \\
\hline (ii) Road side water collections and road potholes & $0.66(-2.14-3.45)$ & 0.644 & $-0.232(-2.52-2.06)$ & 0.843 \\
\hline (iii) Rice fields and hoof prints & $-2.59(-4.33--0.85)$ & $0.004^{\mathrm{a}}$ & $-1.15(-3.84-1.54)$ & 0.402 \\
\hline (iv) Swampy areas & $-0.72(-2.59-1.16)$ & 0.453 & $-1.39(-3.38-0.59)$ & 0.169 \\
\hline (v) Pond water reservoirs & $-2.72(-4.39-1.06)$ & $0.001^{\mathrm{a}}$ & $-1.57(-4.34-1.19)$ & 0.264 \\
\hline $\begin{array}{l}\text { (vi) Small ponds and water collections } \\
\text { on the sides of the bridges }\end{array}$ & $-1.36(-4.42-1.69)$ & 0.382 & $-2.48(-5.07-0.12)$ & 0.062 \\
\hline Salinity (ppm) & $0.57(-0.22-2.37)$ & 0.532 & & \\
\hline Temperature $\left({ }^{\circ} \mathrm{C}\right)$ & $-1.75(-3.36-0.12)$ & $0.035^{\mathrm{a}}$ & $-1.81(-3.62-0.01)$ & 0.051 \\
\hline Total dissolved solids (ppm) & $-0.06(-1.90-1.77)$ & 0.95 & & \\
\hline Conductivity ( $\mu \mathrm{S})$ & $-0.01(-1.93-1.91)$ & 0.992 & & \\
\hline $\mathrm{pH}$ & $-0.74(-1.42-0.06)$ & $0.034^{\mathrm{a}}$ & $-0.42(-1.54-0.7)$ & 0.459 \\
\hline
\end{tabular}

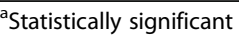

density of individual mosquito species [30]. This study has also demonstrated that various levels of physicochemical parameters have effects on Anopheles and Culex larvae and pupae densities. Information on physicochemical characteristics of the breeding sites may have implication on vector distribution and disease transmission $[9,31]$. This study has shown that both Anopheles and Culex larvae can co-exist in breeding sites despite their differences in breeding ecology. These findings concur with previous studies in western Kenya highlands under semi-field conditions [32] and field environments in northern Ethiopia [33]. There was a higher likelihood of finding Anopheles larvae over Culex. Similar findings were reported in Ghana, where An. coluzzi larvae have a higher tolerance level to faecal contaminated breeding sites than Culex larvae [34]. The difference in densities and the likelihood of finding species-specific larvae shows that the physicochemical parameters have some effects on larval growth $[8,12]$.

In the study area, An. gambiae (s.l.), An. funestus and $C x$. quinquefasciatus were the main vectors of lymphatic filariasis [5, 35, 36] while An. gambiae (s.l.), An. funestus group are responsible for malaria transmission [6, 35]. PCR results showed that within the An. gambiae complex, only two sibling species identified namely An. gambiae (s.s.) and An. arabiensis but no An. merus was identified. A previous study conducted in the same area on vector species composition also did not find $A n$. merus [3]. In addition, four sibling species were identified within the An. funestus group namely An. funestus (s.s.), An. rivulorum, An. leesoni and An. parensis. These findings concur with a previous study conducted in the 
Table 6 Univariate and multivariate association between pupa densities with physiochemical parameters and breeding site-type

\begin{tabular}{|c|c|c|c|c|}
\hline \multirow[t]{2}{*}{ Parameter } & \multicolumn{2}{|l|}{ Univariate } & \multicolumn{2}{|l|}{ Multivariate } \\
\hline & Coefficient $(95 \% \mathrm{Cl})$ & $P$-value & Coefficient (95\% Cl) & $P$-value \\
\hline \multicolumn{5}{|l|}{ Breeding type category } \\
\hline (i) Rain water collections & 1 & & 1 & \\
\hline $\begin{array}{l}\text { (ii) Road side water collections and } \\
\text { road potholes }\end{array}$ & $0.39(-1.3-2.09)$ & 0.65 & $-0.39(-2.71-1.93)$ & 0.741 \\
\hline (iii) Rice field and animal hoof prints & $-1.24(-2.12--0.37)$ & $0.005^{\mathrm{a}}$ & $-0.98(-1.85--0.12)$ & $0.028^{a}$ \\
\hline (iv)) Swampy areas & $-1.15(-2.11--0.19)$ & $0.018^{\mathrm{a}}$ & $-1.28(-2.06--0.50)$ & $0.001^{\mathrm{a}}$ \\
\hline (v) Pond water reservoirs & $-1.89(-2.68--1.09)$ & $<0.001^{\mathrm{a}}$ & $-1.57(-2.23--0.90)$ & $<0.001^{\mathrm{a}}$ \\
\hline $\begin{array}{l}\text { (vi) Small ponds and water collection } \\
\text { on the sides of the bridges }\end{array}$ & $0.75(-0.04-1.53)$ & 0.063 & $-0.07(-0.43-0.30)$ & 0.712 \\
\hline \multicolumn{5}{|l|}{ Physicochemical parameters } \\
\hline Salinity (ppm) & $-0.23(-1.44-0.86)$ & 0.618 & & \\
\hline Temperature $\left({ }^{\circ} \mathrm{C}\right)$ & $-1.66(-2.57--0.75)$ & $<0.001^{\mathrm{a}}$ & $-0.69(-1.44-0.06)$ & $<0.001^{\mathrm{a}}$ \\
\hline Total dissolved solids (ppm) & $-0.72(-2.12-0.68)$ & 0.312 & & \\
\hline Conductivity $(\mu \mathrm{S})$ & $-0.64(-1.94-0.66)$ & 0.334 & & \\
\hline $\mathrm{pH}$ & $0.15(-0.26-0.56)$ & 0.481 & & \\
\hline
\end{tabular}

${ }^{\mathrm{a} S}$ Statistically significant

north-eastern Tanzania, which reveal the occurrence of the four-sibling species of the An. funestus group [2]. Among the sibling species identified An. funestus (s.s.) was the most common [2,37].

The present study has shown that mosquito breeding sites varied from fresh to highly polluted habitats. Fresh mosquito breeding habitats are clean waters with little organic matter dissolved while highly polluted mosquito breeding habitats are sites with high levels of salinity, ammonium ions and organic pollution as described by Kudom [34] and Sattler et al. [38]. In the context of this study, highly polluted habitats are those with high tds, conductivity, salinity, temperature and $\mathrm{pH}$. High concentrations of these parameters can be harmful to some species of mosquitoes [30, 39].

Physicochemical parameters survey in various mosquito breeding sites has revealed that the quality of water ranges from fresh to highly polluted [29], both with the presence of various densities of Anopheles and Culex mosquito larvae. The present study has demonstrated for the first time the occurrence of Anopheles in polluted habitats in rural settings of Tanzania. This was an unexpected finding especially in this rural setting for An. gambiae (s.l.), which usually breed in fresh water. Similar findings have been reported in previous studies conducted in the city of Dar es Salaam [38] and urban Lagos, Nigeria [39], but unlike our study, these studies were conducted in urban settings. This finding contradicts some previous findings, which reported that Anopheles mosquito breeds in fresh unpolluted water [6]. Unlike Anopheles, the Culex mosquito has been reported to breed in polluted waters such as septic tanks [40], pit latrine and soakage pits [41].

The occurrence of Anopheles larvae in breeding sites with high levels of salinity and conductivity suggests a gradual potential emergence of tolerance to
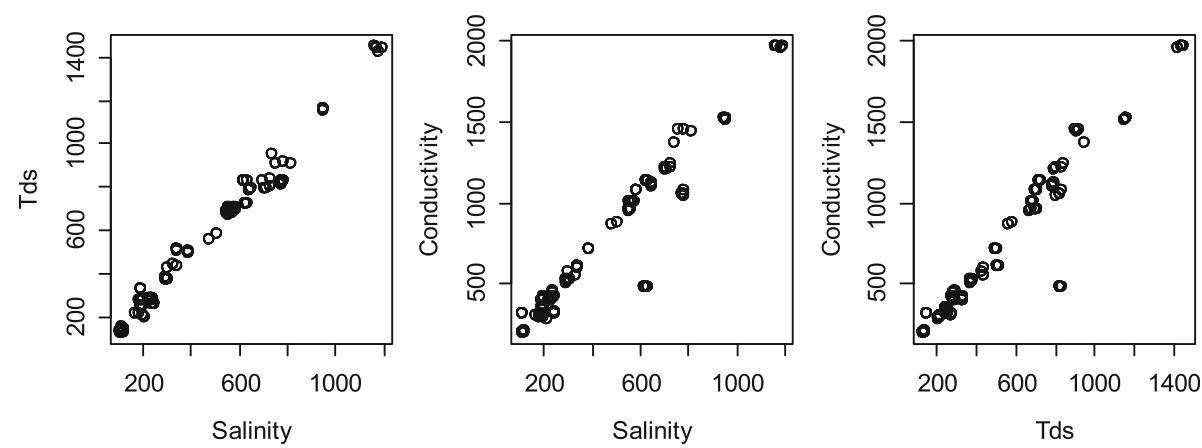

Fig. 3 Scatter plots showing the relationship between total dissolved solids (tds), salinity and conductivity 
these physicochemical parameters [2]. Nevertheless, the occurrence of high levels of physicochemical parameters such as conductivity, nitrate, sodium and ammonia in mosquito breeding sites are suspected to originate from the use of agricultural pesticides $[9,42,43]$. This tolerance could pose a serious threat to the success of various larvicidal products with similar chemical structure and activity with chemicals in the breeding sites. Moreover, emerged adult mosquito from such breeding sites are likely to be selected for inherent and acquired resistance to chemical products used for mosquito vector control even in the absence of prior exposure [10, 43, 44].

Mean densities of Anopheles larvae and Culex larvae and pupa, were highest in road side water collections and road potholes. Both species were collected in water with tds ranging from mineral springs to high contamination, salinity ranging from fresh water to polluted water and conductivity ranging from domestic to highly polluted water while $\mathrm{pH}$ was weak basic. This study has revealed that these mosquito species breed in a diverse range of habitats, contrary to current knowledge that Anopheles prefers to breed in fresh (unpolluted) clear water [6-8].

Mean larvae and pupae densities of Anopheles and Culex were highest in roadsides water collections and road potholes. These breeding sites were less permanent, small and resulting from human activities $[45,46]$ such as agriculture and infrastructural development. They also had the highest mean $\mathrm{pH}$ (above 7). These findings are in line with other reports which have revealed that Anopheles gambiae can breed in water with $\mathrm{pH}$ between 4 and 7.8 if there is sufficient aquatic food to consume [12]. Our findings are contradictory to those of Adebote et al. [47], which reported that Anopheles prefers low pH.

The lowest Anopheles and Culex larvae and pupae densities were recorded in pond water reservoirs, which were natural and permanent water bodies. In such kinds of larval habitats, the presence of predators and competitors could suppress mosquito larvae densities [45]. Pond water reservoirs had the highest mean temperature, tds, salinity and conductivity. These findings imply that the mentioned physicochemical properties may have been higher and beyond levels that could be tolerated by the identified mosquitoes. For instance, temperature above $30{ }^{\circ} \mathrm{C}$ affects growth and survival of Anopheles larvae because these are an enzyme-catalysed reaction and they decrease at high temperatures [8].

Anopheles larvae abundance was higher in waters with high levels of salinity and conductivity compared to Culex. These findings concur with a previous study conducted in northern Ethiopia [33] and in Accra, Ghana [10]. High levels of conductivity may be due to the application of agricultural pesticides and herbicides $[9,43]$. Agricultural water runoff and sewage leaks are normally higher in nutrients such as chloride, phosphate and nitrate ions, therefore, leads to higher concentrations of dissolved solids which can influence conductivity [29]. Upper percentiles of salinity and conductivity significantly favoured Anopheles larvae compared to lower percentiles. Similar findings were also reported by Kweka and others in western Kenya highlands [31]. In this study, none of the physicochemical parameters was found to be significantly associated with the presence of Culex. These findings are contradictory to observations reported from Ethiopia [33] by Dejenie and others indicating that $\mathrm{pH}$ and conductivity were positively associated with the presence of Culex.

The upper percentiles of salinity and conductivity were significantly associated with increased density of Anopheles larvae. The mean square root of larval density was significantly higher by 1.86 in upper percentiles of salinity compared to lower percentiles. These findings are similar to a previous study conducted on the Kenyan coast on $A n$. merus [30]. Unlike the present study, a study conducted in Nigeria reported that conductivity and tds appeared to have no influence on Anopheles larval density [8]. In the present study, upper percentiles of temperature were found to be associated with increased density of Anopheles larvae, although not statistically significant. This finding concurs with previous studies that, Anopheles larval abundance increases with increasing temperature from 28 to $32{ }^{\circ} \mathrm{C}[8,10,31,48]$.

Unlike Anopheles larvae, for Culex larvae, temperature and $\mathrm{pH}$ were both associated with a decrease in larval density. Across all breeding sites, water mean $\mathrm{pH}$ ranged from 8.0 to 8.8 . Breeding sites with high $\mathrm{pH}$ range are not ideal for mosquito breeding and survival due to free ammonia, which tends to increase with rising $\mathrm{pH}$. Neutral $\mathrm{pH}$ between 6.8 and 7.2 is a preferred breeding site by mosquitoes. Therefore, outside this range mosquito eggs, larvae and pupae growth are reduced, and $\mathrm{pH}$ range below 4.5 or above 10 , mortality occur [11]. The only temperature was found to be associated significantly with a decrease in pupae density by 1.66 .

\section{Conclusion}

The present study has found that the abundances of Anopheles and Culex larvae are affected by physicochemical parameters present in their breeding sites. However, the present study has revealed for the first time the occurrence of Anopheles larvae in polluted breeding sites in rural settings in Tanzania. In addition, the study has found both Anopheles and Culex mosquito larvae co-existing in breeding sites despite their differences in breeding ecology under natural conditions. These mosquitoes are vectors of malaria and lymphatic filariasis. This information is very useful in understanding the breeding behaviour of Anopheles mosquitoes in polluted habitats. The possible reasons for tolerance to a higher level of physicochemical parameters among Anopheles mosquitoes population need to be investigated. 


\section{Abbreviations}

Cl: Confidence interval; CRERC: Ethics Review Committee; GEE: Generalised estimating equation; MRCC: Medical Research Coordinating Committee; NIMR: National Institute for Medical Research; OR: Odds ratio; ppm: Parts per million; SD: Standard deviation; tds: Total dissolved solids; TRAction: Translating Research into Action; USAID: United States Agency for International Development

\section{Acknowledgements}

The authors are grateful to the support provided by the American People through the United States Agency for International Development (USAID) Sub-agreement \# FY13-G05-6990, Under Cooperative Agreement No. GHSA-00-09-0015-00 Translating Research into Action (TRAction) Project. The authors wish to acknowledge the invaluable contributions from various people and institutions. We express our gratitude to field workers and Muheza community for the corporation they provided to us during the implementation of this study.

\section{Funding}

This work was supported by the United States Agency for International Development (USAID) Sub-agreement \# FY13-G05-6990, Under Cooperative Agreement No. GHS-A-00-09-0015-00 Translating Research into Action (TRAction) Project.

\section{Availability of data and materials}

The data supporting the conclusions of this article are included within the article.

\section{Authors' contributions}

BE conceived the study, design and performed the study, participated in the field, contributed to interpretation of results and drafted the manuscript; RM critically reviewed the manuscript; BPM analysed the data, contributed to interpretation of results and critical review of the manuscript; WNK contributed to overall study design and critically reviewed the manuscript; FWM contributed to overall study design and critical review of the manuscript. All authors read and approved the final manuscript

\section{Competing interests}

The authors declare that they have no competing interests.

\section{Consent for publication}

Not applicable.

\section{Ethics approval}

This study was approved by the Medical Research Coordinating Committee (MRCC) of the National Institute for Medical Research (NIMR) (Ref. No. NIMR/ HQ/R.8a/Nol.IX/1613) and Kilimanjaro Christian Medical University College Research and Ethics Review Committee (CRERC) (Ref. No. 885). The study did not involve the collection of human and animal tissues. However, technicians involved in sample collection were protected during collecting water samples by wearing gum boots and gloves.

\section{Publisher's Note}

Springer Nature remains neutral with regard to jurisdictional claims in published maps and institutional affiliations.

\section{Author details}

${ }^{1}$ Kilimanjaro Christian Medical University College, P.O. Box 2240, Moshi, Tanzania. ${ }^{2}$ National Institute for Medical Research, Headquarters, P.O. Box 9653, Dar es Salaam, Tanzania. ${ }^{3}$ National Institute for Medical Research, Amani Centre, P.O. Box 81, Muheza, Tanzania. ${ }^{4}$ National Institute for Medical Research, Tanga Centre, P.O. Box 5004, Tanga, Tanzania.
}

\section{Received: 11 November 2016 Accepted: 11 June 2017} Published online: 24 June 2017

\section{References}

1. Derua YA, Alifrangis M, Hosea KM, Meyrowitsch DW, Magesa SM, Pedersen EM, et al. Change in composition of the Anopheles gambiae complex and its possible implications for the transmission of malaria and lymphatic filariasis in north-eastern Tanzania. Malar J. 2012;11:188.
2. Derua $Y$, Alifrangis M, Magesa S, Kisinza W, Simonsen P. Sibling species of the Anopheles funestus group, and their infection with malaria and lymphatic filarial parasites, in archived and newly collected specimens from northeastern Tanzania. Malar J. 2015;14:1-8.

3. Kweka EJ, Mahande AM, Assenga C, Lyatuu EE, Mosha FW, Mwakalinga SB. Short communication; vector species composition and malaria infectivity rates in Mkuzi Muheza District, north-eastern Tanzania. Tanzan J Health Res. 2008;10:46-9.

4. Mwakitalu M, Malecela M, Pedersen E, Mosha F, Simonsen P. Urban lymphatic filariasis in the city of Tanga, Tanzania, after seven rounds of mass drug administration. Acta Trop. 2013;28:692-700.

5. Simonsen P, Derua Y, Magesa S, Pedersen E, Stensgaard A, Malecela M, et al. Lymphatic filariasis control in Tanga region. Tanzania: status after eight rounds of mass drug administration Parasit Vectors. 2014;7:507.

6. Manguin S. Anopheles mosquitoes: new insights into malaria vectors. Croatia: InTech; 2013.

7. WHO. Manual on practical entomology in malaria. Part II. Methods and Techniques. Geneva; World Health Organization; 1975.

8. Imam AA, Deeni Y. Common types of Anopheles gambiae breeding habitats in north western Nigeria. J Innov Res Eng Sci. 2014;4:496-504.

9. Garba Y, Olayemi IK. Spartial variation in physicochemical characteristics of wetland rice fields mosquito larval habitats in Minna, north Central Nigeria. In: International conference on agricultural, ecological and Medical sciences, Feb 10th-11th; 2015. p. 11-4.

10. Kabula BI, Attah PK, Wilson MD, Boakye DA. Characterization of Anopheles gambiae s.l. and insecticide resistance profile relative to physicochemical properties of breeding habitats within Accra metropolis, Ghana. Tanzan J Health Res. 2011;13:163-87.

11. Kwasi B, Biology A, Kumasi T. Physico-chemical assessment of mosquito breeding sites from selected mining communities at the Obuasi municipality in Ghana. J Environ Earth Sci. 2012;2:123-30.

12. Oyewole IO, Momoh O, Anyasor GN, Ogunnowo A, Ibidapo C. Physicochemical characteristics of Anopheles breeding sites: impact on fecundity and progeny development. African J Environ Sci Technol. 2009;3:447-52.

13. Balls MJ, Bødker R, Thomas CJ, Kisinza W, Msangeni H, Lindsay S. Effect of topography on the risk of malaria infection in the Usambara Mountains, Tanzania. Trans R Soc Trop Med Hyg. 2004;98:400-8.

14. Githeko AK, Ayisi JM, Odada PK, Atieli FK, Ndenga BA, Githure Jl, et al. Topography and malaria transmission heterogeneity in western Kenya highlands: prospects for focal vector control. Malar J. 2006;5:1-9.

15. Fox C, Westneat D. The quarterly review of biology. Evol Behav Ecol. 2010;85:504.

16. Minakawa N, Seda P, Yan G. Influence of host and larval habitat distribution on the abundance of African malaria vectors in western Kenya. Am J Trop Med Hyg. 2002;67:32-8.

17. Hay SI, Sinka ME, Okara RM, Kabaria CW, Mbithi PM, Tago CC, et al. Developing global maps of the dominant Anopheles vectors of human malaria. PLoS Med. 2010;7

18. Sinka ME, Bangs MJ, Manguin S, Rubio-palis Y, Chareonviriyaphap T, Coetzee $M$, et al. A global map of dominant malaria vectors. Parasit Vectors. 2012;5:69.

19. Shililu JI, Tewolde GM, Brantly E, Githure JI, Mbogo CM, Beier JC, et al. Efficacy of Bacillus thuringiensis israelensis, Bacillus sphaericus and temephos for managing Anopheles larvae in Eritrea. J Am Mosq Control Assoc. 2003;19:251-8.

20. Carlson JC, Byrd BD, Omlin F. Field assessments in western Kenya link malaria vectors to environmentally disturbed habitats during the dry season. BMC Public Health. 2004;4:33.

21. Liu X-B, Liu Q-Y, Guo Y-H, Jiang J-Y, Ren D-S, Zhou G-C, et al. Random repeated cross sectional study on breeding site characterization of Anopheles sinensis larvae in distinct villages of Yongcheng City. People's Republic of China Parasit Vectors. 2012;5:58.

22. Takken W, Verhulst NO. Host preferences of blood-feeding mosquitoes. Annu Rev Entomol. 2013;58:433-53.

23. Curtis CF. Restoration of malaria control in the Madagascar highlands by DDT spraying. Am J Trop Med Hyg. 2002;66:1.

24. URT. 2012 population and housing census; population distribution by administrative areas, United Republic of Tanzania. 2013.

25. Emidi B, Kabula B, Tungu P, Massaga J, Kisinza W. Insecticide resistance testing in malaria vectors in Tanzania: challenges in mosquito sampling a nd rearing under field conditions. Rwanda J Ser F Med Heal Sci. 2015;2(1):60-4.

26. Gillies MT, de Meillon B. The Anophelinae of Africa south of the Sahara; Ethiopian zoogeographical region. 2nd ed. Institute for Medical Research: Johannesburg, South Africa; 1968. 
27. Edwards F. Mosquitoes of the Ethiopian region, III Culicine adults and pupae. London and Dorking, UK: Oxford University Press; 1941.

28. Scott J. Species complex authentication by PCR, Anopheles gambiae complex. In: Chapter 8: Field Techniques; 1993. p. 95-6.

29. Kevin R, Daniel K, Christine K, Katie F, Alex C. Conductivity, salinity and total dissolved solids. 2014: http://www.fondriest.com/environmental-measurements/ parameters/water-quality/conductivity-salinity-tds. Accessed on 18 August 2016.

30. Kipyab PC, Khaemba BM, Mwangangi JM, Mbogo CM. The physicochemical and environmental factors affecting the distribution of Anopheles merus along the Kenyan coast. Parasit Vectors. 2015;8:221.

31. Kweka $E$, Zhou G, Munga $S$, Lee $M$, Atieli $H$, Nyindo $M$, et al. Anopheline larval habitats seasonality and species distribution: a prerequisite for effective targeted larval habitats control programmes. PLoS One. 2012;7(12):e52084.

32. Kweka E, Zhou G, Beilhe LB, Dixit A, Afrane Y, lii TMG, et al. Effects of Cohabitation between Anopheles gambiae s.s. and Culex quinquefasciatus aquatic stages on life history traits. Parasit Vectors. 2012;5:33.

33. Dejenie T, Yohannes M, Assmelash T. Characterization of mosquito breeding sites in and in the vicinity of Tigray microdams. Ethiop Health Sci. 2011;21:57-66.

34. Kudom AA. Larval ecology of Anopheles coluzzii in Cape Coast, Ghana: water quality, nature of habitat and implication for larval control. Malar J. 2015;14:447.

35. Derua YA, Kisinza WN, Simonsen PE. Differential effect of human ivermectin treatment on blood feeding Anopheles gambiae and Culex quinquefasciatus. Parasit Vectors. 2015;8:130.

36. Simonsen P, Derua Y, Kisinza W, Magesa S, Malecela M. Lymphatic filariasis control in Tanzania: effect of six rounds of mass drug administration with ivermectin and albendazole on infection and transmission. BMC Infect Dis. 2013;13:335

37. Lwetoijera DW, Harris C, Kiware SS, Dongus S, Devine GJ, McCall PJ, et al. Increasing role of Anopheles funestus and Anopheles arabiensis in malaria transmission in the Kilombero Valley, Tanzania. Malar J. 2014;13:331.

38. Sattler MA, Mtasiwa D, Kiama M, Premji Z, Tanner M, Killeen GF, et al. Habitat characterization and spatial distribution of Anopheles sp. mosquito larvae in Dar es Salaam (Tanzania) during an extended dry period. Malar J. 2005:4:4.

39. Awolola TS, Oduola AO, Obansa JB, Chukwurar NJ, Unyimadu JP. Anopheles gambiae S.S. Breeding in polluted water bodies in urban Lagos, southwestern Nigeria. J Vector Borne Dis. 2007;44:241-4.

40. Burke R, Barrera R, Lewis M, Kluchinsky T, Claborn D. Septic tanks as larval habitats for the mosquitoes Aedes aegypti and Culex quinquefasciatus in Playa-Playita, Puerto Rico. Med Vet Entomol. 2010;24:117-23.

41. Curtis CF, Malecela-Lazaro M, Reuben R, Maxwell CC. Use of floating layers of polystyrene beads to control populations of the filaria vector Culex quinquefasciatus. Ann Trop Med Parasitol 2002;96 Suppl 2:97-104.

42. Nkya TE, Akhouayri I, Kisinza W, David J. Impact of environment on mosquito response to pyrethroid insecticides: facts, evidences and prospects. Insect Biochem Mol Biol. 2013;43:407-16.

43. Philbert A, Lyantagaye SL, Nkwengulila G. A review of agricultural pesticides use and the selection for resistance to insecticides in malaria vectors. Adv Entomol. 2014:2:120-8.

44. Nkya T, Akhouayri I, Poupardin R, Batengana B, Mosha F, Magesa S, et al. Insecticide resistance mechanisms associated with different environments in the malaria vector Anopheles gambiae: a case study in Tanzania. Malar J. 2014;13:28.

45. Mereta ST, Yewhalaw D, Boets P, Ahmed A, Duchateau L, Speybroeck N, et al. Physico-chemical and biological characterization of anopheline mosquito larval habitats (Diptera: Culicidae): implications for malaria control. Parasit Vectors. 2013;6:320.

46. Correia W, Varela I, Spencer H, Alves J, Duarte EH. Characterization of mosquito breeding sites in the Cape Verde islands with emphasis on major vectors. Int J Mosq Res. 2015;2:192-9.

47. Adebote DA, Oniye SJ, Muhammed YA. Studies on mosquitoes breeding in rock pools on inselbergs around Zaria, northern Nigeria. J Vector Borne Dis. 2008;45:21-8.

48. Munga S, Vulule J, Kweka EJ. Response of Anopheles gambiae s.I. (Diptera: Culicidae) to larval habitat age in western Kenya highlands. Parasit Vectors. 2013;6:13.

\section{Submit your next manuscript to BioMed Central and we will help you at every step:}

- We accept pre-submission inquiries

- Our selector tool helps you to find the most relevant journal

- We provide round the clock customer support

- Convenient online submission

- Thorough peer review

- Inclusion in PubMed and all major indexing services

- Maximum visibility for your research

Submit your manuscript at www.biomedcentral.com/submit 